\title{
8. helburua: guztiontzako hazkunde ekonomikoa, enplegu betea eta lan duina sustatzea. Urrutitik hamalau, gerturatu eta lau
}

\author{
(Promote economic growth, full employment and decent work for all. \\ You can't judge a book by its cover)
}

\author{
Aitor Bengoetxea Alkorta*, Enekoitz, Etxezarreta Etxarri \\ Lanaren eta Gizarte Segurantzaren Zuzenbidea (UPV/EHU) \\ GEZKI (Gizarte Ekonomia eta Zuzenbide Kooperatiboaren Institutua) Institutua \\ IT 1327-19 Euskal Unibertsitate Sistemaren Ikerketa Taldea: \\ «Gizarte ekonomia eta bere Zuzenbidea».
}

\begin{abstract}
LABURPENA: Garapen Iraunkorrerako 8. Helburuak (GIH) aski ezagunak diren kontzeptu sozioekonomiko sakonen alde egiten du, guztiontzako sustatu nahian hazkunde ekonomiko jarraitua, inklusiboa eta jasangarria, enplegu betea eta produktiboa eta lan duina. Artikulu honetan, kontzeptu nagusi horien irakurketa egiten saiatu gara, lau atal desberdinduz: hazkunde ekonomiko jarraitua, enplegua eta lana, enplegu betea, eta lan duina. Gure balorazioa oso kritikoa izan da. Hazkunde ekonomiko jarraituari dagokionez, paradigma klasikoan mugitzen da, Barne Produktu Gordinaren eta per capita errentaren inguruan. Tresna horiekin nekez birbideratuko da egungo eredu ekonomiko suntsitzailea ekonomia jasangarri baterantz eta nekez ezabatuko da pobrezia, helburuak dioen moduan. Per capita errenta neurtzaile oso mugatua da: ez du balio desberdintasunak eta pobrezia neurtzeko. Per capita errentaren alternatiba gisa, Giza Garapearen Indizea proposatuko genuke, baina 8. GIHak ez du aintzat hartu. Enplegu beteari dagokionez, egungo eredu liberala aldatu ezean, enplegua esparru ekonomikoko faktore produktiboa izanik oinarrizko giza eskubide bat baino gehiago, nekez joko dugu enplegu beterantz: kontrako norabidean goaz. Lan duina helburu desiragarria da, baina, langileen lan-baldintzak merkatu-logikaren barruan erabakitzen diren bitartean, ez dugu lan duinik lortuko, historiak aski argi erakutsi digun bezala. Azken finean, GIHen enplegu- eta lan-helburuak ondo idatzita daude, baina haien aldeko borondate politiko irmorik eta horren tamainako neurri juridikorik ez dugu ikusten.
\end{abstract}

HITZ GAKOAK: 8. GIHa, hazkunde ekonomiko jarraitua, barne-produktu gordina, per capita errenta, giza garapenaren indizea, enplegu betea, lan duina, justizia soziala.

\begin{abstract}
The 8th Sustainable Development Goal (SDG) supports well-known deep-seated socio-economic concepts that seek to promote sustained, inclusive and sustainable economic growth, full and productive employment and decent work for all. In this article we have tried to read these main concepts, distinguishing four sections (sustained economic growth; employment and work; full employment, and decent work). Our assessment has been very critical. In terms of sustained economic growth, it moves in the classical paradigm, around Gross Domestic Product and per capita income. With these tools it is unlikely that the current destructive economic model will be redirected towards a sustainable economy, eliminating poverty, as the goal says. Per capita income is a very limited measure, it does not serve to measure inequality and poverty. As an alternative to per capita income, we would propose the Human Development Index, which is not recognized by $8^{\text {th }}$ GIH. When it comes to full employment, unless the current liberal model changes, as employment is a productive factor in the economic sphere rather than a basic human right, we are unlikely to move towards full employment, we are going in the opposite direction. Decent work is a desirable goal, but while the working conditions of workers are decided within the logic of the market, we are not going to achieve decent work, as history has shown us clearly enough. After all, the employment and labor goals of the GIH are well written, but we do not see a firm political will in their favor and legal measures of that size.
\end{abstract}

KEYWORDS: SDG 8, sustained economic growth, gross domestic product, per capita income, human development index, full employment, decent work, social justice.

* Harremanetan jartzeko / Corresponding author: Aitor Bengoetxea Alkorta, Lanaren eta Gizarte Segurantzaren Zuzenbidea (UPV/EHU), GEZKI (Gizarte Ekonomia eta Zuzenbide Kooperatiboaren Institutua) Institutuko Zuzendaria, IT 1327-19 Euskal Unibertsitate Sistemaren Ikerketa Taldea: "Gizarte ekonomia eta bere Zuzenbidea». - aitor.bengoetxea@ehu.eus https://orcid.org/0000-0002-0947-4793.

Nola aipatu / How to cite: Bengoetxea Alkorta, Aitor; Etxezarreta Etxarri, Enekoitz (2021). «8. helburua: guztiontzako hazkunde ekonomikoa, enplegu betea eta lan duina sustatzea. Urrutitik hamalau, gerturatu eta laun; Ekaia, ale berezia 2021, 143-154. (https://doi.org/10.1387/ekaia.22120).

Jasotze-data: 2020, urriak 15; Onartze-data: 2021, urriak 18

ISSN 0214-9001 - elSSN 2444-3255 / (C) 2021 UPV/EHU

(7) $\odot$ Lan hau Creative Commons Aitortu-EzKomertziala-LanEratorririkGabe 4.0 Nazioartekoa lizentzia baten mende dago 


\section{SARRERA}

2015eko irailean, Nazio Batuen Erakundean (NBE), Garapen Iraunkorrerako 17 Helburu (GIHak) ezarri ziren, eta hala bildu ziren garapen iraunkorraren hiru dimentsioak: ekonomikoa, soziala eta ingurumenekoa. Asmo nagusiak hauek dira: pobrezia amaitzea, gure planeta babestea eta guztion oparotasuna bermatzea. GIH bakoitzak bere helmugak ditu, eta asmoa helburu horiek 2030erako lortzea da.

Garapen iraunkorrerako 2030eko adierazpenean, honako hau esaten da gure gaiaren inguruan: «Hazkunde ekonomiko iraunkor, inklusibo eta eutsi baterako behar diren baldintzak sortuko ditugu, baita oparotasun partekatua eta guztiontzako lan duina ere, kontuan hartuta garapen- eta gaitasun-maila nazionalak».

Lan honetan, 8. helburua landuko dugu: «Guztiontzako hazkunde ekonomiko jarraitua, inklusiboa eta jasangarria, enplegu betea eta produktiboa eta lan duina sustatzea».

8. helburuaren garrantziaz jabetzeko, Nazio Batuen Erakundeak azpimarratu du pobrezia desagertzeko (1. helburua) ezinbestekoak direla ongi ordaindutako enplegu egonkorrak. Abiapuntua latza da; izan ere, gaur egun, 2.200 milioi pertsona pobreziaren atalasearen azpitik bizi dira munduan, erreferentzia gisa eguneko Amerikako Estatu Batuetako 2 dolar hartuta.

Helburuaren hartzaileak pertsona guztiak gara; beraz, 8. GIHak esparru subjektibo unibertsala dauka. Geroago ikusiko dugun moduan, bereziki azpimarratzen da talde zaurgarriak ere helburuaren esparruan daudela. Are gehiago, talde zaurgarriek hazkunde ekonomiko inklusiboaren, enpleguaren eta lan duinaren hartzaile protagonista nagusiak izan behar lukete.

Bestalde, helburuan sustatu aditza erabiltzen da, eta horrek, juridikoki bederen, badu garrantzia. Helburua ez da denon enplegua eta lan duina bermatzea, sustatze hutsa baizik. Horrek gehiago kokatzen gaitu politika publikoen norabidearen arloan (sustatu), pertsonen eskubideen arloan baino (bermatu).

Artikulu honetan, 8. GIHa irakurtzen eta berrirakurtzen saiatuko gara, gakotzat jotzen ditugun lau elementu garatuz, atal hauetan: hazkunde ekonomiko jarraitua; enplegua eta lana; enplegu betea, eta lan duina.

\section{HAZKUNDE EKONOMIKO JARRAITUA}

8. helburuan aipatzen den hazkunde ekonomikoaren berrikuspen kritikoa egiteak oinarri-oinarrian dauden eta egiazkotzat jo izan diren zenbait uste ekonomiko auzitan jartzera garamatza. 

eta lan duina sustatzea. Urrutitik hamalau, gerturatu eta lau

Hala, hazkunde ekonomiko jarraituak mundu mailan — baina bereziki herrialde aurreratuetan - inoiz baino ongizate material handiagoa sortu duen neurri berean, ezin da ukatu herrialde aberatsetako ongizate material hori mundu mailako lehengaien eta laneskuaren arpilatze-politiken gainean eraiki dela. Mendekotasun-harreman horrek mundu mailako desparekotasun ekonomikoak areagotzea eta muturreko pobrezia eta aberastasunak handitzea ekarri du, datu objektiboek aditzera ematen duten gisan. Era berean, gehituko genuke hazkunde horren bidez zer neurtzen den eta zer ez begiratzeak ere baduela garrantzia: merkatu-prezioa duten jarduera ekonomikoak soilik neur ditzakegu; ez, ordea, preziorik gabeko jarduerak, merkatutik pasatu ez arren bizitzaren sostengurako funtsezko jarduerak badira ere.

Ideia horretan apur bat gehiago sakonduz, 8. helburuan ezarritako lehen helmugak ${ }^{1}$ per capita errentan oinarritzen du politika ekonomiko ororen xedea. Ikusmira oso hertsia da hori, ordea. Izan ere, ekonomia bere osotasunean ulertu ahal izateko, adierazle ahula da per capita errenta, eta aspaldidanik jarri da auzitan [1]. Izan ere, zer neurtzen du per capita errentak? Errenta nazionala herrialde bateko biztanleen artean nola banatzen den aztertzeko kalkulua batez besteko aritmetiko bidez eginez, erabat itsutzen gara aberastasun horren benetako banaketarekin, batezbestekoak ez baitu azaltzen muturreko balioen zenbatekoa, ez eta haien bilakaera ere. Hala, herrialde batean per capita errentak berbera izaten jarrai lezake gizatalderik aberatsenak aberastuko balira, talderik pobreenak areago pobretuko liratekeen neurri berean. Gizarte-desparekotasunak muturrera eramanda, per capita errentak berdina izaten jarrai lezake, baita handiagoa ere, kasu askotan. Zer ari gara neurtzen, beraz, era horretako adierazle makroekonomikoen bitartez?

Giza garapenaren adierak adierazle horren gaitasun azaltzaile mugatua mahaigaineratu du, eta, besteak beste, Giza Garapenaren Indizea (GGI) proposatu du adierazle osatuago gisa. Adierazle konposatu horretan, per capita errentaz gain, herrialde baten hezkuntza mailaren eta iraupenaren aldagaiak ere biltzen dira. Neurgailu berri hori baliatuz gero herrialdeen garapen maila neurtzeko, oso bestelakoa da agertzen zaigun argazkia. Ez agian hain bestelakoa ere, baina bai esanguratsuki ezberdina. Izan ere, herrialde aberatsenetako zenbait per capita errentaren bidez neurtuz gero, ez dira GGIren bidez neurturiko herrialderik garatuenen top ten-ean ageri. Horrek ondorio argi bat uzten du agerian: errentarik altueneko herrialde guztiak ez dira herrialderik garatuenak. Izan ere, badira, badirenez, errenta apalagoa izanik ere garapen maila handiagoa erdietsi duten herriak. Erren-

\footnotetext{
1 «Bere horretan eustea per capita hazkunde ekonomikoari, ezaugarri nazionalen arabera, eta barne-produktu gordina urtean gutxienez $\% 7$ haz dadila bermatzea aurrerapen txikieneko herrialdeetan».
} 
tarik baxuenak dituzten herrialdeek, ordea, gehien-gehienean garapenik baxuenak dituzten berberak izan ohi dira. Hazkunde ekonomikoa, hortaz, ongizatearen aurrebaldintza gisa hartu izan dugu, baina halakorik baieztatzeak ñabardura asko onar ditzake. Ongizate-sistema publikoek, gizarte-prestazio sendoek, ehun industrial eta sindikal sendoek, edo hezkuntzak eta giza kapitalak zerikusi zuzenagoa dute, zalantzarik gabe, herrialdeen garapen mailarekin, hazkunde mailak baino.

Hari horri eutsiz, balio erantsi handia duten eta eskulanean intentsiboak diren sektoreei arreta jartzera gonbidatzen gaitu bigarren helmugak ${ }^{2}$. Nola neurtu, ordea, balio erantsi hori? Barne-produktu gordinaren eraketan erantsitako balio monetarioa ote da neurgailu bakarra, ala balegoke beste neurgailurik balio erantsi horrentzat? Balio soziala? Balio kulturala? Ugariak dira zentzu horretan egindako proposamen alternatiboak. Haizu bekigu gure iritzian azken boladan iritzi publikoan modu agerikoan eragiten ari diren bi proposamen nagusi aipatzea: oinarrizko errentaren proposamena, batetik, eta bizitzaren iraunkortasunarena, bestetik.

Oinarrizko errentaren inguruko eztabaida konstatazio horrexetatik abiatzen da: egun oraindik indarra duten lan ordainduen kopuru bat ekonomiaren digitalizazio- eta robotizazio-prozesuek desagerraraz lezakete, eta, beraz, badirudi lana eta ongizatea parekatzen dituen ustea bera dagoela (lana da ongizate-iturri nagusia) gero eta kinka larriagoan [2]. Larrialdi klimatikoak mahai gainean jarritako trantsizio sozioekologikorako premiak ere baliabide irensleak edo jarduera oso kutsatzaileak diren zenbait lanen desagerpenera eraman behar gintuzke, zentzu onean. Oinarrizko errentak, neurri batean, pertsonen ongizate materiala haien merkatu-jardueretatik bereiztea du oinarri filosofiko nagusia, datorkeen lan eskasia bati erantsi behar baitzaio egungo lan askok nekez sortzen dutela ongizate materialik, «zabor-lanak» diren neurrian.

Bigarren proposamenak, bizitzaren iraunkortasunari erreparatzen dionak, begiratu ekofeminista bati erantzuten dio [3]. Ekonomia ekologiko eta feministako hainbat autorek erdigunera ekarri dute babestu beharreko funtsezko sektoreen afera: sektore ekonomiko estrategikoenak bizitza iraunarazten duten horiek direla barneratu behar genuke, hots, osasun-, hezkuntza- eta zaintza-lanak; elikadura; ur- eta energia-hornidurak, eta abar. Sektore horiek guztiak lehenesteko, jarduera ekonomiko horien desmerkantilizaziorako premia ere mahaigaineratu da, gogoeta hauxe ekarriz lehen planora: ekonomiak ekoizten dituen zein ondasun eta zerbitzuk onar lezakete merkatu-logika bat eta zeinek ez? Zeinek behar lukete merkatuko

2 «Produktibitate ekonomikoaren maila handiagoak lortzea, dibertsifikazioaren, modernizazio teknologikoaren eta berrikuntzaren artean, besteak beste, balio erantsi handia duten eta eskulan asko erabiltzen duten sektoreei arreta eskainiz». 
gorabeheretatik salbu? Eta nola babestu jarduera horiek merkatu-logiketan jaustetik? Haien hornidura publikoa da biderik zuzen eta egokiena? Edo komunitateak ahalduntzen dituzten autoeraketa-formulek babesten dituzte hobekien jarduera horiek merkantilizaziotik?

Desmerkantilizazioaren gaia hartu dugunez gero, lotura zuzena agertzen du, orobat, laugarren helmugan ${ }^{3}$ zehazturiko helmuga nagusiekin. Izan ere, mundu mailako ekoizpen- eta kontsumo-ohitura eraginkorrak sustatzeak eta hazkunde ekonomikoa ingurumen-degradaziotik bereizteak zerikusi zuzena du merkatuaren bestelako disfuntzio batzuekin. Izan ere, merkatuak, esleipen-mekanismo hutsa den neurrian, ez du bereizten kontsumo eraginkorra ez-eraginkorretik, ez eta natura-degradaziotik ere. Badirudi merkatuko eragileek (ekoizle zein erosleek) kontzientzia hartzearen bitartez aurre egin nahi zaiola disfuntzio horri, baina kontzientziaziorako bide horrek askotan talka egiten du merkatuko pizgarri logikekin, sarri askotan produkturik merkeenak baitira inpaktu ekologiko larrienak izan ohi dituztenak. Asko dira zentzu horretan bideratzen ari diren proposamen eta estrategia konkretuak, eta ekonomia zirkularra da azkenaldian onarpen mailarik altuena erdiesten ari direnetako bat.

Funtsean, ekonomia modu zirkularrean hautemateak zera bilatu nahi luke: gure ekoizpen- eta kontsumo-ohiturak naturak sostenga ditzakeen mailetara ekartzea eta jarduera ekonomikoa naturaren erreprodukzio mailari doitzea, dela materialen fluxu ziklikoak planteatuz (produktuen bizi-zikloak luzatuz, berrerabiliz, hondakinak lehengai bilakatzeko birziklatuz), dela energia berriztagarrien aldeko hautuak eginez. Dinamika berri horiek ekonomia «birtokikotzeko» edo «bertakotzeko» logikak hobestea ekarri behar lukete, baina ahaztu gabe trantsizioa modu justuan egin behar litzatekeela, prozesu horietan herrialderik pobretuenak izan bailitezke ostera ere kaltetuenak, lehengaien mundu mailako esportazio-dinamiketara espezializatzera behartuak diren heinean.

Garapenera bideraturiko politikak sustatzeak (3. helmuga) ${ }^{4}$, beraz, kontuan hartu behar lituzke elementu horiek guztiak: jarduera ekonomiko produktiboak eta enplegu duinak sortzeaz bat, bizitzaren iraunkortasunetik eratorritako ikuspegi estrategikoa ere barneratu behar litzateke. Zein jarduerak onar lezaketen merkatu-logika bat (etekinen maximizatzean oinarrituriko

\footnotetext{
3 «Hemendik 2030era, pixkanaka hobetzea munduko baliabideen ekoizpen eta kontsumo eraginkorra, eta hazkunde ekonomikoa ingurumenaren degradaziotik bereizten saiatzea, Kontsumo eta Ekoizpen Modalitate Jasangarriei buruzko Programen Hamar Urterako Esparruarekin bat etorriz, garatutako herrialdeetatik hasita».

${ }_{4}$ «Garapenera bideratutako politikak sustatzea, honako alderdi hauei babesa emango dietenak: ekoizpen-jarduerak, lanpostu egokien sorrera, ekintzailetza, sormena eta berrikuntza; eta mikroenpresen eta enpresa txiki eta ertainen eraketa eta hazkuntza sustatzea, baita finantza-zerbitzuak eskuratzearen bidez ere».
} 
praktikak) eta zeinek egon behar duten hertsiki babestuak logika horietatik. Izan ere, egungo garapen-ereduarekiko alternatibotzat jotzen diren proposamen askok, baita ekonomia zirkularrak ere, arrisku bera dute: azkenean hazkunde alternatibo bat sustatzea, hazkundearekiko alternatiba izan beharrean, hazkundea bera baita auzitan jarri beharreko lehen premisa, zalantzagarria denez gero zer neurritan egiten dion on herrialde pobretuen egoerari, eta zer esanik ez oreka ekologiko iraunkorrari.

Finean, mundu mailako herrialde ororentzat garapen-eredu berbera planteatzeak gehiago du ikusmira kolonial eurozentrikotik, garapenerako lankidetzatik baino. Garapenaren desmitifikazioa eta dekolonizazioa ere beharrezkoak izango dira, beraz, deshazkundearen proposamenarekin bat eginez [4], herrialde bakoitzak libreki eta bere kosmobisioarekin bat eginez hautatzen duen garapen-eredua babesteko, eta, «garapen»erako lankidetza praktikatu beharrean, soil-soilik lankidetzara mugatzeko munduko herrialdeen artean harremanak izatearen logika.

\section{ENPLEGUA ETA LANA}

«Enplegu betea eta produktiboa nahiz lan duina sustatzea» helburu gisa finkatzen denean, gaian murgiltzeko unean, komeni da, lehenik eta behin, enplegua eta lana kontzeptuak aztertu eta bereiztea.

Enplegu produktiboaz ari garenean, funtsean, ondasun edo zerbitzuen ekoizpenera bideratutako lan ordainduaz ari gara, eta pertsona oro bi egoera hauetakoren batean dago: enplegua duena (landuna) edo enplegurik ez duena (langabea). Zuria edo beltza.

Tradizionalki, lan erreproduktiboa ez da lan produktibotzat hartu. Lan erreproduktiboa bizitzaren erreprodukzioaren ingurukoa da; umezaintza, nagusien zaintza eta, oro har, etxeko lanak dira, eta gehiengo zabalaz emakumeek egiten dute lan hori. Lan hori ordaindua ez denez, teoria ekonomiko klasikoak ez du produktibotzat hartzen, eta, besteak beste, ez da kontuan hartzen herrialdeen barne-produktu gordina kalkulatzerakoan. Posizionamendu feministatik, justizia osoz, aldarrikatzen da lan erreproduktiboaren balioa aitortzea, benetako lana delako, eta gainera ezinbestekoa, iraunkortasunaren ikuspegitik.

Badira zenbait enplegu produktibo ordaindu mota. Sailkapen nagusia besteren konturako langilea (soldatapekoa) eta norberaren konturako langilea (autonomoa) desberdintzen dituena da. Soldatapekoak enpresaburu batentzat egiten du lan, lan-kontratu baten bitartez; langilearen lanak eragindako mozkina enpresaburuak eskuratzen du, eta horren truke soldata ordaintzen dio langileari. Autonomoak ez du inoren mende lan egiten, eta beraren lanaren fruitu diren zerbitzu edo ondasunek eragindako mozkinak langileak berak eskuratzen ditu. 

eta lan duina sustatzea. Urrutitik hamalau, gerturatu eta lau

Funtzionario publikoen kasua besteren konturako enplegatuen artean kokatzen da, baina administrazio publiko batek jasotzen eta ordaintzen du funtzionarioaren lana. Autonomoen alderdian, aipaturiko autonomo indibidualaz gain, badago beste aukera bat: autoenplegu kolektiboa. Langile talde batek bere buruari, kolektiboki, enplegua ematean datza. Lan elkartuko kooperatibak dira modalitate horren erreferentzia nagusia ${ }^{5}$.

Beraz, 8. GIHa enpleguaz ari denean, aipaturiko edozein enplegu motataz ari da: besteren konturakoa (sektore pribatuko soldatapekoak nahiz sektore publikoko funtzionarioak); eta norberaren konturakoa den autoenplegua, indibiduala (autonomoak) edo kolektiboa (lan-kooperatibak).

Enplegua eta lana bereizteko, esan genezake enplegua dela lanerako sarbidea eta irteera. Pertsona batek enplegua lortzen duenean, lanean hasten da, eta, enplegua galtzen duenean, lana uzten du. Horregatik, lan duinaz ari garenean, lan-baldintzez ari gara (soldata, lanaldia, oporrak, etab.), baina lan duina edukitzeko aurrebaldintza enplegua lortzea da.

\section{ENPLEGU BETEA}

Atal honetan, saiatuko gara 8.5, ${ }^{6} 8.6^{7}$ eta $8 \mathrm{~b}^{8}$ helmugen mamia aztertzen.

Enplegu beteaz ari garenean, lan egin ahal eta nahi duten pertsona guztiek (populazio aktiboa) enplegua edukitzeaz ari gara, langabeziarik ez egoteaz, langabezia sortzen baita lan egin ahal eta nahi dutenek enplegurik lortzen ez dutenean.

Ez da planteatzen langabeziaren tasa \% 0 izatea, beti egongo baita langabezia frikzionala deritzona: langile kopuru bat, proportzionalki oso txikia normalean, langabezian dagoena bere azken enplegua galdu eta enplegu berria lortu bitarteko trantsizioan. Horregatik, enplegu betetzat hartzen da populazio aktibo osoak enplegua izatea, langabezia frikzionala kenduta.

Berez, enplegu betearen kontzeptua lan egiteko eskubidearen isla da. Txanponaren beste aldea. Lan egin nahi duen guztiak enplegua lortzen

\footnotetext{
${ }^{5}$ Kooperatibismoan eta, oro har, gizarte-ekonomian sakontzeko, ikus www.gezki.eus (2021eko irailaren 29an kontsultatua).

6 «Hemendik 2030era, enplegu osoa eta produktiboa eta lan egokia lortzea emakume eta gizon guztientzat, gazteak eta desgaitasunen bat dutenak barne; eta balio bereko lanarengatik soldata berdina eman dadila lortzea».

7 «Hemendik 2020ra, nabarmen murriztea enplegurik ez duten eta ikasten edo gaitzen ari ez diren gazteen proportzioa».

8 «Hemendik 2020ra, gazteek enplegua lortzeko mundu-mailako estrategia bat garatzea eta martxan jartzea, eta Lanaren Nazioarteko Erakundearen Enplegurako Munduko Ituna aplikatzea».
} 
badu, lanerako eskubidea gauzatuz, enplegu betea egongo da. Eta lan egiteko eskubidea aspaldi dago aitortuta nazioarteko zuzenbidean, GIHen esparru den NBEn, Giza Eskubideen Aldarrikapen Unibertsalean (1948) ${ }^{9}$. Aspaldiko eskubide bat errepikatzen du, beraz, 8. GIHak.

Enplegu betearen alde serio aritzeko, lanerako eskubidea oinarrizko eskubide gisa babestu eta lehenetsi behar litzateke, eta gaur egun ikus dezakegu sarritan faktore ekonomiko huts gisa tratatzen dela, kostu ekonomiko soila, enpresaren mozkinentzat errentagarria ez bada erraz sakrifikatzen dena, langileak kaleratuz.

Ideia bat egiteko, mundu mailan enplegu beteaz zein urrun gauden ikusteko, Lanaren Nazioarteko Erakundearen arabera (LNE), 2015ean, 204 milioi pertsona langabezian zeuden mundu osoan.

Are zailagoa da talde zaurgarri izendatzen diren kolektiboen egoera. 8. GIHak batzuk aipatzen ditu (emakumeak, gazteak, desgaitasunen bat dutenak), baina gehiago daude (gizarte-bazterketa egoeran daudenak, adinez nagusi direnak, eta abar). Talde zaurgarriak definitzea ez da erraza, baina estatistikek argi erakusten dute talde horietako gizabanakoek zailago dutela enplegua lortzea [5]. 8. GIHak dioen moduan, enplegu betea guztiontzat lortu nahi bada, arreta berezia eskaini behar zaie talde zaurgarriei, enplegua lor dezaten. Aztertzen ari garen GIHak bereziki azpimarratzen ditu gazteak, hainbat eskualdetan gazteen langabezia-tasa oso altua delako, eta, noski, gazteak lurraldeen etorkizuna direlako.

Estatistikek frogatzen dutenean talde bateko kideek zailtasun handiagoa dutela enplegua lortzeko, langabe guztiekin konparatuta, horrek bide ematen du talde zaurgarri horien alde ekintza positiboko neurri publikoak bultzatzeko (kontrataziorako dirulaguntzak, eta abar), pertsona horiek enplegua lortzeko aukera-berdintasuna lortzearen bidean, beste langabeen maila berean.

\section{LAN DUINA}

Atal honetan, $8.7^{10}$ eta $8.8^{11}$ helmugek diotena berrirakurtzen saiatuko gara.

\footnotetext{
9 23. art.: «Pertsona orok du lan egiteko eskubidea».

10 «Berehalako neurri eraginkorrak hartzea ezinbesteko lana amaitzeko, amaiera ematea egungo esklabotasun-moduei eta pertsonen salerosketari, eta haurren lanaren forma okerrenak (errekrutatzea eta haur soldaduak barne) debekatu eta kenduko direla bermatzea; eta, hemendik 2025era, amaiera ematea haurren lanari, bere forma guztietan».

11 «Lan-eskubideak babestea eta lan-ingurune segurua eta arriskurik gabea sustatzea langile guztientzat, migratzaileak barne, eta, bereziki, emakume migratzaileentzat eta enplegu prekarioak dituztenentzat».
} 
Has gaitezen azpimarratzen lanaren adierak itzal zabal duela. Euskaraz, bizkaieraz, beharra erabiltzen da lanaren sinonimo gisa. Gaztelaniazko «trabajo» hitza latinezko tripalium terminotik dator, hiru makilako tortura tresna bat. Latinoamerikan, pasar trabajo sufritzearen sinonimoa da. Gogoeta sakonerako bide ematen duten elementuak dira horiek, artikulu xume honetaz haratago doazenak.

Eta, iraganean, lanaren gogortasunagatik eta eragiten duen sufrikarioagatik, oso hedatua egon da lana derrigorrezko gisa planteatzea, behartu gisa, esklaboen zeregin gisa. Aristotelesek eta haren gisako beste filosofo miretsi batzuek esklabotza justifikatu ohi dute [6]. Grezia klasikoan pertsona jasotzat jotzen zirenak pentsalariak, erlijiosoak, militarrak edo politikariak ziren. Lana, derrigorrezkoa eta gogorra, esklaboen gauza zen. Ikuspegi juridikotik, esklaboak gauzak ziren, beren jabeen objektu. Eskubiderik gabeko gauza.

Geroago, feudalismoan, nekazaritza-arloan, morroien derrigorrezko lana zen nagusi. Jauntxoen morroiak. Juridikoki pertsonak ziren, baina materialki bizi-baldintza oso kaxkarrak zituzten, jauntxoek besteak beste morroiekiko ius malectractandi delakoa baitzeukaten.

Ibilbide historiko azkar bat egiten jarraituz, esan behar dugu XVIII. mendearen amaiera aldeko Industria Iraultzaren eta Frantziako Iraultzaren eragina nabarmena izan zela lanaren arloan. XIX. mendean, industrializazioa garatzen zen neurrian, langile asko nekazaritzatik hiri industrialetara igaro ziren, eta industriako lan-baldintzak erabakitzeko irizpidea Frantziako Iraultzako liberté eta égalité izan ziren.

Horren arabera, lana librea zen, hots, esklaboen eta morroien derrigorrezko lanaren kontzeptua gainditu zen. Lan-baldintzei dagokienez, enpresaburuaren eta langilearen arteko harremana berdinen arteko harreman libre bat zen, eta mugarik gabeko askatasuna zegoen lan-baldintzak zehazteko. Horren ondorioz, langileen esplotazioa izugarri hedatu zen, enpresek eskaintzen zizkieten baldintza gogorrak ezinbestean onartu behar zituztelako (16 orduko lanaldiak, haurrak barne, biziraupen-soldatak, eta abar), langabezian geratu nahi ez bazuten. Edozein muturreko baldintza izanda ere, laissez faire, laissez passer. Eta, formalki, juridikoki, lan librea, eta langileak askatasunez onarturiko lanbaldintzak.

Haurrei dagokienez, historikoki ez dira babestuta egon lanaren ikuspegitik, ez esklabotza-sisteman, ez morroien ereduan, ezta industrializazio osteko fase kapitalistan ere. Haurren egoera bereziki deitoragarria delako azpimarratzen ditu haurrak 8. GIHak.

Iraganean derrigorrezkoa, gutxietsia eta hain gogorra izan den lanaren ideia gainditu nahian, lan duinaren ideia nagusitu da gure egunotan, batez 
ere Lanaren Nazioarteko Erakundearen eskutik. ${ }^{12}$ Lan duinaren oinarrizko ideia langileak eskubideak edukitzea da, hots, lana mugatua egotea, derrigorrezko esklaboetatik eta XIX. mendeko esplotaziotik aldenduz.

Lan duina lan-baldintza duinak dituen lana da [7], besteak beste bidezko soldata eta segurtasun fisikoa bermatzen dituena. Baita gizarte-babesa duen lana ere, gizarte-segurantzako prestazioak jasotzen dituena langileak lanik egin ezin duenean gaixotasun, istripu, jubilazio edo antzeko arrazoiengatik.

Lan eskubideduna esaten dugunean, gaur egun, lan formala esan nahi dugu, legez arautua, lan informala, eskubiderik gabekoa, oso hedatuta baitago mundu mailan. NBEk emandako datuen arabera, mundu mailan, 2016an, langileen \% 61ek ekonomia informaleko lana zeukan, eskubiderik gabekoa ${ }^{13}$.

Lan duinaren ideiaren oinarria, ikuspegi juridikotik, Lanaren Nazioarteko Erakundearen Filadelfiako Aldarrikapenean (1944) aurkitu dezakegu, zehazki «lana ez da merkantzia bat» aldarrikatzen denean [8]. Esaldi labur horrek asko esan nahi du. Lana merkantzia baldin bada, edozein lan-baldintza erabaki daiteke, eskaintzaren eta eskariaren arteko orekaren arabera, eta logika horrek, bereziki XIX. mendean, langileen esplotazio itzela ekarri du.

Horregatik du berebiziko garrantzia lana merkantzia bat ez dela aldarrikatzeak, horrek esan nahi duelako zuzenbideak - zehazki, lanaren zuzenbideak - lan eskubideduna bermatuko duela, esplotazioa ekarri duen merkatuaren logikatik ihes eginez [9].

Dena den, Filadelfiako Aldarrikapenaren garaia (1944) eta gaur egungoa oso desberdinak dira, lanaren zuzenbidearen ikuspegitik. 1980ko hamarkadara bitartean, bereziki munduaren mendebaldean, lan-zuzenbidea loratu zen. Hamarkada horretan hasi zen indarra hartzen haize-ufada neoliberala, Milton Friedman-ek, Friedrich Hayek-ek eta beste ekonomialari neoliberal batzuek planteatuta, eta gerora bereziki Margaret Thatcher-ek eta Ronald Reagan-ek fede handiz aplikatutakoa Erresuma Batuan eta Amerikako Estatu Batuetan, hurrenez hurren.

Eta, harrezkeroztik, korronte neoliberala puztuz eta lanaren zuzenbidea proportzionalki argalduz joan dira [10]. Izan ere, laissez faire, laissez passer liberalak lanaren merkantilizazioa bultzatzen du funtsean; lanaren zuzenbideak, aldiz, lan duina eta ukatu ezin diren eskubideak dituen lana planteatzen ditu (gutxieneko soldata, gehienezko lanaldia, eta abar).

12 www.ilo.org (2021eko irailaren 29an kontsultatua). LNE 1919. urtean lehen mundu-gerrari amaiera eman zion Versaillesko Itunaren ondorioz sorturiko erakundea da. Haren helburu nagusia mundu osoan justizia soziala lortzea da, bake unibertsalaren mesedetan. 1999az geroztik, mundu osoan decent work edo lan duina du berariazko helburu.

13 https://www.un.org/sustainabledevelopment/es/economic-growth (2021eko irailaren 29an kontsultatua). 

eta lan duina sustatzea. Urrutitik hamalau, gerturatu eta lau

Eta hor dago koxka: lana merkantzia bat da, ala ez?

Lan duina aldarrikatzen badugu, erantzunak ezezkoa izan behar du ezinbestean.

\section{GURE GOGOETA ETA ONDORIOAK}

2015ean adostu ziren GIHak patxadaz irakurri eta aztertu ostean, burura datorren lehen ideia da egia dela paperak dena onartzen duela. Besteak beste, gaixotasunik gabeko mundua helburu bat dela irakur daiteke ber$\tan .{ }^{14}$ Gehitxo, ala?

8. GIHari dagokionez, gure azterketan azaltzen saiatu garen arrazoiengatik, oso kritikoak izan behar dugu.

Hazkunde ekonomiko jarraituari dagokionez, orain arte ezagutu duguna izan da herrialde aberatsen hazkundea herrialde pobreen lepotik etorri dela eta arrakala gero eta gehiago areagotu dela. Per capita errentaren totemak gabezia nabarmenak ditu, batezbesteko hutsa baita, aberaste eta pobretzeak neurtzen ez dituena, desberdintasuna areagotu arren. Giza Garapenaren Indizea (GGI) adierazle askoz osatuagoa da, beste aldagai batzuk ere biltzen baititu, hala nola herrialde baten hezkuntza maila eta iraupena. Halakoak baliagarriak izan daitezke herrialde baten benetako garapen maila ezagutzeko, eta GIHek ez dituzte aipatu ere egiten.

Aurrera begira, are gehiago COVID-19aren eragina kontuan hartzen badugu, benetan inklusiboa izan daitekeen oinarrizko errenta ez da aintzat hartzen 8. GIHan, eta bizitzaren iraunkortasunerako giltzarri diren sektore ekonomikoen desmerkantilizazioa ere ez da planteatzen. Iraunkortasunaren ikuspegitik, oso interesgarria den ekonomia zirkularra, jarduera ekonomikoa naturaren erreprodukzio mailara egokitzean datzana, eta hori ere ez da aintzat hartzen. Hazkunde ekonomiko jarraitua da planteatzen dena.

Lan-arlora etorrita, enplegu betea eta lan duina planteatzea, egun bizi dugun eredu sozioekonomiko liberalaren testuinguruan, boluntarismoaren esparruan kokatu behar dugu. Egungo eredu neoliberal kapitalista, datuek diotenez, pertsonen arteko desberdintasun sozioekonomikoa areagotzen ari da, eta hori da eredu horretatik espero zitekeen eta espero daitekeen ondorioa. Lanaren merkantilizazioaren aurrean muga sendoak juridikoki bermatuak jartzea planteatu zuen, argi eta garbi, Filadelfiako Aldarrikapenak, lana merkantzia bat ez dela esanez. Baina merkatu librearen dogma gailentzen ari da mundu mailan, eta horrek, besteak beste, langileen hainbat eskubide jatea ekarri du.

14 «Gaixotasun eta gabeziarik gabeko mundu bat nahi dugu». 
GIHek mahaigaineratzen dituzten helburuetarako bidea hartzeko, norabidea aldatu beharko litzateke, eta hori ez da boluntarismoarekin edo hitz larriekin lortzen, baizik eta benetako berdintasunaren aldeko bestelako politika ekonomikoekin eta politika horiek bermatu eta bideratuko dituzten neurri juridikoekin.

Izan ere, zuzenbideak, hard law atalean, egungo sistema neoliberal kapitalistaren zutabeak ondo finkatzen eta lotzen ditu: enpresa-askatasuna, jabetza pribatua eta herentzia. Bitartean, justizia sozialaren eta pobreziaren aurkako ekimenak soft law esparru ahulean kokatzen dira, indar bermagarria duen zuzenbide gogorretik at, sustapenaren kategorian.

Adibide bat? Adibide on bat? Gertuko adibide bat? GIHak.

\section{BIBLIOGRAFIA}

[1] SEN, A., STIGLITZ, J. eta FITOUSSI, J.P. 2010. Mismeasuring our lives: why GDP doesn't add up. The New Press, New York.

[2] ARCARONS, J., RAVENTÓS, D. eta TORRENS, L. 2017. La renta básica: una propuesta racional y justa, Ediciones del Serbal, Bartzelona.

[3] CARRASCO, C. 2014. «Economía, trabajos y sostenibilidad de la vida», in Zenbaiten artean, Sostenibilidad de la vida. Aportaciones desde la Economía Solidaria, Feminista y Ecológica. REAS Euskadi, Bilbo.

[4] LATOUCHE, S. 2007. Sobrevivir al desarrollo. De la descolonización del imaginario económico a la construcción de una sociedad alternativa. Icaria, Bartzelona.

[5] BENGOETXEA ALKORTA, A. 2020. «La inclusión socio-laboral de los grupos vulnerables. Colectivos y formas de inclusión a través del trabajo». CIRIEC-España, Revista Jurídica de Economía Social y Cooperativa, 36, $15-53$.

[6] MONTOYA MELGAR, A. 2020. «Sobre la dignidad del trabajo». Nueva Revista Española de Derecho del Trabajo, 231,31-48.

[7] MONEREO PÉREZ, J.L. 2019. La dignidad del trabajador. Dignidad de la persona en el sistema de relaciones laborales. Ediciones Laborum, Murtzia.

[8] SUPIOT, A. 2010. L'Esprit de Philadelphie. La justice sociale face au marché total. Seuil, Paris.

[9] BENGOETXEA ALKORTA, A. 2012. «Derecho a un trabajo digno: el trabajo no debe ser una mercancía», in Zenbaiten artean, ORDEÑANA GEZURAGA, I. (zuz.), La declaración universal de los derechos humanos: ayer, hoy y mañana / Giza eskubideen aldarrikapen unibertsala: atzo, gaur eta bihar. Aranzadi, Zizur Txikia.

[10] BENGOETXEA ALKORTA, A. 1999. «Neoliberalismoaren eragina LanZuzenbidean», in Zenbaiten artean, DE ABAJO GONZÁLEZ, A. (zuz.), Neoliberalismoa edo egungo gizartea irudikatzeko zenbait zertzelada. Udako Euskal Unibertsitatea, Donostia. 